\title{
A Viral Shift in Higher Education?
}

\author{
By Simon Boxall
}

The COVID-19 pandemic has led to a viral change in the way universities across the globe deliver education. This rapid spread of delivering information to students online has been as much a pandemic as the disease itself.

In the early days of lockdowns and restrictions during the spring of 2020 , many universities changed their teaching to online delivery at a time when most of us thought it would be for a few weeks or months at most. It was a novelty for students to see the inside of their professor's home and meet the family dog while the instructor tried to deliver a learned lecture on deep ocean circulation. Many of us tried out various backdrops for our lectures - the garden, the study, the living room? In our house, with my wife and I vying for the best backdrop for our live, online lectures, one of us often ended up with the bedroom. This wasn't helped by the fact that at this stage our house was undergoing very major restoration and so lectures were usually accompanied by the dulcet tones of a jackhammer or a builder's whistling. In the end, I found the button that puts up a false backdrop, and since then all my lectures are delivered in front of an iceberg-though it's surreal when the dog still pops up. We also had to rethink the concept of exams. Setting a classic exam when the student is at home assumes a lot about their integrity, and so it required a rapid rethink on how we assess students.

We all had a very steep learning curve for the myriad delivery platforms: Zoom, Teams, and Blackboard Collaborate, to name but a few. All are packages that few of us had ever heard of at the beginning of 2020, let alone used on a daily basis. Ensuring that when we shared our screens, we only shared PowerPoint and not that scathing draft email to the dean that we weren't planning to actually send was paramount, as was hoping that the housebound kids hadn't just taken up all of the bandwidth on some "intellectual" video game.

The novelty of the situation and the "all in it together, Dunkirk spirit" meant it worked-not well, but everyone accepted it. At that stage, late spring, most of our practical work had been completed for the academic year and so not much was lost. As 2020 moved forward with more restrictions and a wider spread of the virus, higher education had to go through more major changes. Nine months in, we can no longer evoke that Dunkirk spirit. Our planning, like a pregnancy, has come to term and we are now expected to deliver high-level and effective learning to all of our students. Within our faculty, major events like undergraduate field courses, and summer schools for prospective future oceanographers, were at first postponed and eventually canceled. We then had to think how the pedagogy and learning outcomes would stand up to online teaching, something that NASA and NOAA have achieved for years at a public information level but which universities have in the main avoided. But there was a nagging worry that if we could do it online, wouldn't there be cafes full of unemployed professors eking out their one coffee a day?

For some subjects, online learning is generally achievable with limited loss of outcomes. For others, like medicine, engineering, and, of course, oceanography and marine biology, it is less straightforward. Lectures can be delivered online, as can tutorials. Extended essays can replace exams, which in my opinion is a far better way of assessing how much of a subject a student has truly grasped. Even a computer-based practical can work well as long as each student has a computer running standard freely available software and internet access. My first-year practical, which sets out to show why Southampton has a double high tide, uses online data and any spreadsheet package. In the past, I ran it three times in our hot, overcrowded computer room with three postgrads running around helping solve problems. This year, I ran it once, for a longer session, from my garden, and students could share their screens with me if they had issues. They worked at their own pace, and the feedback was such that, from here on in, I will continue to run it online.

Working at sea is not an easy experience to replicate as some form of intellectual computer game. Thus, over the summer our faculty built up a backlog of work that needed to be achieved as faceto-face, in situ learning this fall. Several of my colleagues have tried to video themselves working on the boat and explaining what they are doing, but it is like going to a restaurant and having someone explain how great the food is...but not allowing you to try it.

There is a further and more crucial issue, and that is student satisfaction with their courses. Students (and parents) understandably want to feel that they are getting value for their money, and this is evident in the different responses around the globe. In Sweden, for example, higher education is free for all Swedish and EU nationals through the master's level. The fees are covered by the state, and for many there are loans and bursaries for 
living costs. In other countries, there is an annual tuition fee payable by students, which, in the Netherlands, comes to just a little over $\$ 2,000$ and can be covered by the state for students from poorer backgrounds. The rest of the costs are met by the state. It is no accident that countries like Sweden have some of the best educated people in the world. In the UK, students have to take out a loan for fees that are $\$ 12,500$ for home and EU students, and then they have living costs on top of that. In the United States, many universities have even higher tuition fees.

This issue of value for money has led to pressure to resume on-campus learning as the new semester begins. In Sweden, students don't feel the same loss as someone paying out $\$ 12,500$-plus for an online course, and the government there has instructed universities to close their doors and go online as far as is possible. In the US and the UK, where students are well aware of the money their education is costing them, they are far more critical of the online experience. This is evident in a growing number of fee strikes by UK university students. While universities are a blend of research and education, research grants pay for the postdocs and other research staff-the fees pay for most of the running costs of the university and the salaries of the professorial staff. If students withhold fees, are not residing in university halls, and not eating in campus dining halls, then many higher education institutions will rapidly head toward insolvency. There is pressure on us to keep our doors open for on-campus learning. An article published in August 2020 in Nature (Marris, 2020) showed a fairly even split between online and in-person classes across US universities. Neither the US nor the UK governments have issued a clear dictate on how we should progress nor have they provided additional financial support. In the UK, the government has even suggested that students could expect a partial refund of fees from their respective institutions.

The media have appointed students the new bad guys of the COVID-19 pan- demic. Irresponsible behavior, wild parties, and general "mixing" from different regions of their countries have been cited as causes for the rapid spread of the virus. However, the more common responsible and ordered behavior of most twenty-first century students seems to have gone unnoticed. The New York Times did a survey (https://www.nytimes. com/interactive/2020/us/covid-collegecases-tracker.html) and found that across 1,700 colleges in the United States, there had been, by the middle of November 2020, 321,000 cases with 80 deaths (the majority being staff). It was put forward as a terrible statistic, and for the families of the 80 that died, it surely is. Being a scientist, I worked on the stats. At US universities, there are currently 1,280 staff and students who have or have had COVID-19 per 100,000 and 0.3 per 100,000 who have died. Compare that to the national figures of c. 4,500 per 100,000 and 85 per 100,000 , respectively, for the entire population. In my own university this week, out of over 25,000 students and staff, there are currently 20 active cases (all students) and thankfully no deaths. Not only is this below the national levels for the week, it is also in an environment where all staff and students on campus have weekly tests, and so if anything, the figure would be expected to be much higher.

Universities have strived to make their campus environments as safe as possible. After the longest period of not being on the ocean since I was 12 years old (I was definitely getting itchy feet), we restarted boat-based teaching in October. Rather than 20-25 students crammed in a confined space, the safer working environment means that we now deliver teaching in groups of seven to eight. All of the work is on deck in fresh air, and we all wear masks. The boat is disinfected after each session and left for an hour for the cleaning to be completed. The students feel involved in their subject, and I get to go play with boats again-heaven. It does mean that a practical session that I ran four or five times in the previous year now takes 19 sessions. Similarly for lectures, while many have been delivered online, classes with smaller numbers of students present are being taught in the bigger teaching labs where students can distance themselves from each other and staff.

To date, the pandemic has at best been disruptive and at worst led to the loss of someone close. However, it has shaken up the way we teach marine science. Countless times I have wished we could restructure our degree program and how we teach-now we have been forced into doing just that. The current pandemic has created a significant amount of work for us as we have adapted to delivering course material in new ways, but many of us will continue with these new ways after the pandemic is over, whenever that may be. If anything, students today are getting more for their money than before-it just doesn't seem like that to them. A colleague from Greenland once shared with me a local saying-there is nothing so bad that no good will come from it. But then for Greenland, with 18 cases in total and no deaths, it is not so bad anyway.

In my next column, I will review the various learning techniques adapted by my fellow marine science professors across the globe in the past few months and how well they have gone down with their students. If you are teaching oceanography and marine biology, please drop me an email about how you have adapted your material, how students have responded, and how many of these changes you will take into the future oceanography classroom (simon.boxall@ soton.ac.uk). 厄

\section{REFERENCE}

Marris, E. 2020. Millions of students are returning to US universities in a vast unplanned pandemic experiment. Nature 584:510-512, https://doi.org/ 10.1038/d41586-020-02419-w.

\section{AUTHOR}

Simon Boxall (simon.boxall@soton.ac.uk) is Associate Professor, Ocean and Earth Science, University of Southampton, National Oceanography Centre, Southampton, UK. 